\title{
A spiritual audit of a retail branch of a South African BANK
}

\author{
ERCOLE ALBERTINI \\ DAVID P J SMITH \\ Department of Human Resource Management \\ University of Johannesburg \\ South Africa \\ Correspondence to: Ercole Albertini \\ e-mail: albertin@global.co.za
}

\begin{abstract}
The purpose of this study was to investigate whether or not employees in a branch of one of the leading South African banks are spiritually fulfilled at work, whilst living the values of the bank. The results indicate that employees in the branch are spiritually fulfilled at work, that they seem to be "living the values", and that they believe the branch to be a spiritual workplace. The results are linked to certain interventions in the branch, and these interventions could be replicated across the branch network, reaping the advantages of a spiritual workplace.
\end{abstract}

Keywords: spirituality, spirituality at work, spiritual audit, spiritual fulfilment, spiritual workplace

Work forms an integral part of most people's lives. Studies suggest that the organisation where we work is becoming our most significant community and that work replaces family, friendship circles, church groups and social groups. People are spending more time at work and there are diffuse boundaries between work and personal lives (Parker, 2005, p. 23).

The majority of people's waking time is spent at work, yet people are often asked to leave the major part of themselves their spirit - at home, whilst at the same time, are asked to give one hundred percent of themselves at work (Mitroff Denton, 1999, p. 27). Employers need to recognise that people are more than just a cost to the organisation; that they have souls, dreams, and a need to feel good about what they do.

There is increasing evidence that major transformation is occurring in organisations across the world. Sometimes referred to as the "spirituality movement", organisations that have long been viewed as rational systems, are considering making room for the spiritual dimension, a dimension that has less to do with rules and order, and more to do with meaning, purpose, values and a sense of community (Ashmos Duchon, 2002, p. 3). Spirituality in business, having quietly blossomed for decades, is an established trend that is about to metamorphose into a mega trend (Aburdene, 2005, p. 65).

The organisation on which this research is based is one of the "big four" full service South African banks. This banking institution operates in seventeen African countries and twenty-one countries outside South Africa. This bank has a retail division, as well as a corporate and investment banking division. The retail division has approximately 250 "points of representation" throughout the country.

This research is undertaken in one of the branches situated in Gauteng. This branch has a total of 93 employees and offers the full range of product services offered by the bank. This branch was chosen as it falls within the researcher's mandate in terms of addressing leadership development and is a designated "pilot site" in terms of leadership development and employee satisfaction interventions by the bank itself.

Whilst this branch is typical of other "full service" branches, and may be representative of the branch network in terms of services offered, layout, operational policies and procedures, the findings of the study in this branch cannot be extrapolated onto the entire bank's branch network. This is because of two fundamental differences between all the branches: the individuals that make up the branch (employees) and the leadership of each branch.

Although the entire retail branch network can be seen as one business unit or organisation within the broader bank with the same top leadership, the individuals (employees and branch leadership) in each branch differ in terms of many variables - years of service, age, experience, education, age, gender, ethnicity, qualifications, maturity, personal development, to name but a few.

The findings of this study will be used to investigate (measure) and address another causal dimension of employee satisfaction within the branch - the link between spirituality at work and employee satisfaction as well as the link between spirituality at work and living the bank's values. This link is explained more fully under relevance of the study.

\section{Problem Statement}

According to Zohar and Marshall (2004, p. 14):

The trouble with corporate life is that it is essentially dispiriting. Corporations care about making money. They define work as the pursuit of money. But we are human beings. We are essentially spiritual creatures. We are on a life-long quest for meaning. So our corporate lives exclude what we really care about.

What is the meaning behind the spirit in business? Simply that "it grows out of our desire to celebrate all of ourselves at work" (Aburdene, 2005, p. 66). Humphreys (2000, p. 23) states: "There is a certain sickness in the Western world which appears to afflict people who are over-ambitious, 'high-flyers' and 'successful' in the popular meaning of that word. There are also the people who, more often than not, become fatigued, anxious, depressed, frustrated, unfulfilled and dependent on medication, alcohol or illicit drugs to handle their weariness and moods. Even though work has become a major block to their emotional, social and spiritual growth, they tenaciously hold on to it."

In a study done by Mitroff and Denton (1999, p. 22), respondents who felt they worked in "more spiritual" organisations were able to bring more of their "complete selves" to work. They could deploy more of their creativity, emotions, and intelligence: in 
short, organisations viewed as more spiritual get more from their participants, and vice versa. Another key finding from the research done by Mitroff and Denton (1999, p. 27) was that people do not want to "compartmentalise" or fragment their lives. They want to have their entire beings acknowledged wherever they go.

Many organisations are afflicted by an abundance of disgruntled and demotivated employees who lack a deep sense of commitment towards strategic purpose. This makes it increasingly difficult for such organisations to remain competitive in the rapidly changing global marketplace. The truth is that many employees simply come to work because they have to in order to eat and live. One of the main reasons for this is that the current motivational paradigm does not incorporate the spiritual dimension of employees, and this missing link in the current understanding is considered to be the key to addressing the problems of low employee motivation and the ensuing organisational underperformance and ineffectiveness. The dominant paradigm which is held by most managers is therefore incomplete in that it fails to see people in a whole sense - that is body, heart, mind, and spirit - and by failing to understand the true nature of people it ignores the deeper needs of the whole person (Verrier \& Smith, 2006, p. 1).

In the organisation under study, several reports, diagnostics and employee perception surveys indicate a "myriad of people problems" (Bank HR Board Report, 2006). These reports and diagnoses have not been included for confidentiality reasons. Of particular concern, is that as an employer of choice - as measured by the Deloitte's Best Company to Work For Survey - this organization has dropped from 6th position (out of 100) in 2000 to 54th position (out of 100) in 2005 (Deloitte, Touche \& Tohmatsu, 2006). Reports, diagnoses and surveys in this branch reflect the same trend with respect to employee morale and employee satisfaction.
This study will not attempt to discuss or prove the benefits of spirituality at work. There have been numerous studies and research that prove the benefits of spirituality at work. Amongst others, some of the more popular, scientific and conclusive studies have been conducted by Aburdene (2005), Ashmos and Duchon (2002), Gibbons (2002), Howard and Welbourn (2004), Lamont (2002), Mitroff and Denton (1999), and Zohar and Marshall (2004).

For purposes of this study, it is accepted that some of the more popular and frequently reported benefits of spirituality at work as per the above-mentioned authors are:

- A purpose-driven and meaning-based workplace;

- An appreciation based culture;

- Management practices and decisions that are consistent with spiritual values such as integrity, honesty, love, hope, kindness, respect, and nurturing;

- Management values employees based on who they are not only on what they do;

- Management truly listens and builds a safe place where employees can speak the truth without fear of repercussion;

- A move from command-and-control leadership to horizontal servant leadership; more creative and innovative employees;

- Increased authenticity and genuineness in communication;

- A greater sense of teamwork based on trust; Increased ethical and moral behaviour; increased sense of self-fulfilment, contentment and belonging; and

- Improvement of morale, job satisfaction, loyalty, and ultimately productivity.

In addressing the link between spirituality at work, productivity and profitability, Verrier and Smith (2006, pp.16-22), after consulting the views of various authors on this issue, cite numerous examples of evidence, studies and research that substantiate the link between spirituality at work and

TABLE 1

Evidence of the link between spirituality at work, productivity and profitability

\begin{tabular}{ll}
\hline LINK & AUTHOR \\
\hline - Enhanced individual intuition and creativity, increased honesty and trust within the organisation, increased & Krisnakumar \& Neck \\
commitment to organisational goals, enhanced personal fulfilment. & Thompson \\
- A spirited workplace pays off in customer service. & Thompson - Harvard Business School study \\
- Correlation between corporate culture and profits, with more spirited companies outperforming the others & McKinsey \& Co. \\
by $400 \%$ to $500 \%$ in terms of net earnings, return on investment and shareholder value. & Anderson \\
- Productivity improves and turnover is greatly reduced. & McLaughlin \\
- There is an opportunity cost of not bringing about a spiritual transformation in businesses - potential not & Frederick quoting Mitroff \& Denton \\
realised, sub-optimal decisions, resistance to change, lack of creativity. & \\
- Wilson Learning Company - 39\% of the variability in corporate performance is attributable to the personal & Collins \& Porras \\
- Employees and managers who find the fewest restrictions placed on their beliefs, emotions and actions will & \\
- Organisations that focused on core values were significantly more profitable and long-lasting than & \\
companies that only focused on the bottom line. &
\end{tabular}

TABLE 2

Behavioural guidelines for the bank's eight values

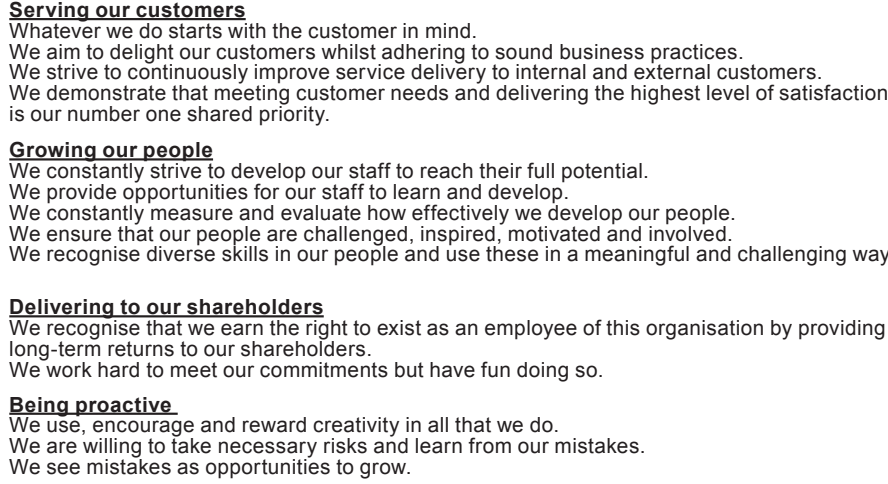

We see mistakes as opportunities to grow.

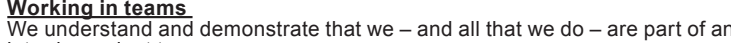
interdependent team

We make individuals feel part of a team.

We strive to make our staff feel accepted and that they belong to a team with common purpose.

Respecting each other

pect and dignity.

We lead from a position of stature and not status.

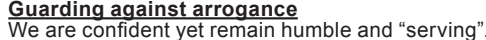

Upholding the highest levels of integrity

作

We help each other identify and develop our limitations in a safe and secure

We encourage our staff to share and learn from each other. 
productivity and profitability. These have been summarised using key words in Table 1.

A dispirited workplace can also manifest itself in low morale, high turnover, burnout, frequent stress-related illness, and rising absenteeism (Thompson in Verrier, 2002, p. 32).

\section{Objectives of this study}

The objectives of this study are:

1. To investigate whether or not the chosen branch is a spiritual workplace with employees in the branch living the values of the bank

2. Are the employees in this branch spiritually fulfilled at work?

More specifically the aim of this study is to answer the following research question:

1. Do employees experience this branch (of the bank) as a spiritual workplace, i.e. do they feel spiritually fulfilled at work?

\section{Relevance of the Study}

This study will contribute to the existing pool of theoretical knowledge on spirituality at work. Research and literature within the South African context regarding the phenomenon of spirituality at work seems to be limited. This study is motivated by the lack of such knowledge, research and understanding in the South African context.

On a practical level the leaders in the company under study may use this knowledge to develop any necessary strategies to create and to sustain a workplace that nourishes both the mind and the spirit of its employees and in so doing both the organisation as well as its employees will enjoy the benefits of this workplace. If this study reveals that:

- The branch exhibits the characteristics of a spiritual workplace, and that the branch employees experience spiritual fulfilment in this branch (workplace), then leadership can develop "lessons learned" and "good practices" for duplication throughout the Bank's branch network.

- The branch is not a spiritual workplace and that the employees are not experiencing spiritual fulfilment in this branch (workplace), then leadership can use the results to address the shortcomings, and develop leaders with skills that will create a culture that characterises a spiritual workplace.

- The bank's values and corresponding behaviours are linked, then management can assess the extent to which employees in the branch are exhibiting the behaviours demonstrative of "living the values".

- The employees in the branch are in fact "living the values", leadership can develop "lessons learned" for duplication throughout the bank to help employees live the values.

\section{The values of the bank}

In 2005 - after extensive research involving employees - the bank launched a set of values. This was done to "create a sense of common understanding and purpose for all employees and

TABLE 3

Peripheral manifestations of the spirit

\begin{tabular}{ll}
\hline Connectedness & Stewardship \\
Centredness & Transcendence \\
Harmony & Total well-being \\
Peace & Congruency between one's True \\
A sense of meaning & North and personal reality \\
A sense of purpose & Positive expectations \\
A sense of integration and wholeness & Religious and/or moral orientation \\
An inner compass & Adding value to self and others \\
Spontaneity & An experience of profound beauty \\
Living what matters most (values) & Wisdom \\
Service & Intuition \\
\hline
\end{tabular}

to act as a framework (or guidelines) for how we as employees behave" (CEO Road show, 2005).

The bank's values are:

- Serving our customers - We do everything in our power to ensure that we provide our customers with the products, services and solutions to suit their needs provided that everything we do for them is based on sound business principles.

- Growing our people - We encourage and help our people to develop to their full potential, and measure our leaders on how well they grow and challenge the people they lead.

- Delivering to our shareholders - We understand that we earn the right to exist by providing appropriate long-term returns to our shareholders. We try extremely hard to meet our various targets and deliver on our commitments.

- Being proactive - We strive to stay ahead by anticipating rather than reacting, but our actions are always carefully considered.

- Working in teams - We and all aspects of our work are interdependent. We appreciate that, as teams, we can achieve much greater things than as individuals. We value teams within and across business units, divisions and countries.

- Guarding against arrogance - We have confidence in our ability to achieve ambitious goals and we celebrate success, but we must never allow ourselves to become arrogant.

- Respecting each other - We have the highest regard for the dignity of all people. We respect each other and what the bank stands for. We recognise that there are corresponding obligations associated with our individual rights.

- Upholding the highest levels of integrity - Our entire business model is based on trust and integrity as perceived by our stakeholders, especially our customers.

Since launching the values, the bank has invested substantial time, money and effort in ensuring that the staff "live the values". To this end the bank has produced a set of "behavioural guidelines" for each of the values for staff to follow and to look out for in the behaviour of their colleagues as evidence that they too are 'living the values'. The behavioural guidelines in respect of the eight values are shown in Table 2.

\section{A personal, interpersonal and professional leadership (PiPL) perspective}

This study is done in the context of the PiPL perspective as the researcher has found this perspective and paradigm on leadership to be the only one that focuses on a whole-person paradigm, including the spiritual dimension. There are many other perspectives and paradigms concerned with human development, leadership and social development.

Leading proponents of these perspectives are in the fields of psychology, sociology, education and other related fields of study. One shortcoming of all these fields of study is the specialised focus on one or maybe two or three dimensions of a person's life. Traditionally professional leadership was synonymous with status, power and output (production at all cost) (Smith, 2005, p. 22).

The PiPL perspective was developed in the mid 1990s by Smith, a professor at the University of Johannesburg. The core focus of PiPL is the concept "leadership" from an inside-out perspective, including:

- Personal Leadership - self mastery

- Interpersonal Leadership - relationship mastery

- Professional Leadership - professional effectiveness.

In the PiPL context the study of Professional Leadership focuses on the workplace with its emphasis on: the importance (worth) of work for a meaningful existence, credible leadership, servan leadership, competent leadership, spiritual fulfilment at work, finding balance between the oneself, one's principles and values, 
one's primary and secondary relationships, and effectiveness in the workplace. Professional leadership in the PiPL context is based on the precepts of spiritual fulfilment at work, relationship building, teamwork, mutual trust and respect, appreciation, empathetic listening, commitment towards a common vision, win-win, synergy, conflict resolution, professional effectiveness and other related principles and values (Smith, 2005).

The spiritual dimension is at the centre of a person's life and totality. As human beings we are alive because the spiritual essence within us is naturally attracted to life in material form. The spiritual dimension can be defined as a search for purpose, meaning, value, inner wholeness, connectedness, harmony, love, morality, beauty, wisdom, hope, vitality, and gratitude. Our spiritual dimension is considered to be our ultimate or core dimension (Smith \& Louw, 2007, p. 19).

The PiPL-perspective presents a holistic model and paradigm that deals with the essence of who and what we are. Individual behaviour is collectivised in organisations. At the core, most organisational problems have common roots - misunderstanding human/individual nature - i.e. lack of a whole-person paradigm (Smith, 2005, p. 28)

Spirituality at work involves "bringing one's whole self to work", including one's spirit. If one views spirituality as a basic human life dimension, then one would have to agree that it is impossible not to take one's spirit to work (Verrier, 2002, p. 35)

\section{Conceptualising spirituality and spirituality at work}

Definitions of spirituality and spirituality at work seem to vary widely. The lack of a clear, accepted definition has hindered the development of useful measures and delayed research that could advance one's understanding of what spirituality at work really is, and one's understanding of the factors that influence the experience of spirituality at work.

This study does not attempt to conceptualise the spiritual life dimension, nor does it seek to conceptualise spirituality at work. However, in order to develop a theoretical foundation as well as guidelines and criteria for the construction of a questionnaire to be used to measure spirituality at work, the viewpoints of various authors on the subjects of spirituality and spirituality at work were consulted. The Smith and Louw (2007) article was found to be one of the most comprehensive studies conceptualising spirituality, and these views will be used for purposes of this study.

\section{Spirituality}

Smith and Louw (2007, p. 25) after studying existing conceptualisations of spirituality conclude that:

Smith's conceptualisation of the spiritual life dimension makes an extremely valuable contribution to this field of study in that it, by way of summary: (a) is comprehensive, descriptive and functional; (b) offers a prioritisation of the manifestations of spirit; (c) paves the way for the developmentof aquestionnairedesignfor themeasurement of the spiritual life dimension; (d) distinguishes clearly between spirit and soul; (e) emphasises the dichotomy of spirit versus ego, and (f) maps out a route to spirituality.

Smith and Louw (2007, pp. 25-27) demonstrate that a definite gap in knowledge exists in the study of the spiritual life dimension and that Smith's perspective offers the following that are lacking or even absent from the current body of knowledge:

- A comprehensive and descriptive conceptualisation;

- A systematic approach. Smith not only provides more information by discussing various manifestations of the spirit, but attempts to order and prioritise these into core (fundamental) and peripheral (less fundamental) manifestations;

- Balance between a functional approach and emphasis on the intangibility of spirit;

- A foundation for developing a questionnaire for measuring spirituality;

- Emphasis on the dichotomy of spirit versus ego;

- Distinction between spirit and soul;

- Clarification in functional terms of what spirit is. Smith clarifies the difference between spirit and soul and translates this abstract concept of spirit into functional terms that can be easily understood and whereby the individual may measure and develop his/her spirituality;

- An indication of the route to spirituality.

\section{TABLE 4}

Viewpoints on what characterises apirituality at work

\begin{tabular}{|c|c|c|}
\hline \multicolumn{2}{|c|}{ CHARACTERISATION OF SPIRITUALITY AT WORK } & \multirow{2}{*}{$\begin{array}{l}\text { AUTHORS ACCORDING TO INDEX } \\
\text { (BELOW) } \\
1 ; 2 ; 3 ; 4 ; 5 ; 6 ; 8 ; 10 ; 12 ; 14 ;\end{array}$} \\
\hline • & $\begin{array}{l}\text { The concept of "the whole person" - People are spiritual beings with the spiritual dimension as foundational requiring } \\
\text { nourishment at work }\end{array}$ & \\
\hline • & Meaningful and challenging work / A sense of vocation / A sense of purpose and meaningful contribution & $2 ; 4 ; 7 ; 11 ; 12 ; 13 ; 14 ; 15 ; 16$ \\
\hline • & Congruence between personal and corporate values & $3 ; 4 ; 6 ; 10 ; 12 ; 14 ; 15 ; 16$ \\
\hline • & Employees share vision, mission and goals & $4 ; 14$ \\
\hline • & Being in the "here and now" & $8 ; 12$ \\
\hline • & Drawing on diversity and a tolerance for diversity of people and differences & $8 ; 12 ; 14 ; 16$ \\
\hline • & Teamwork / Team spirit & $4 ; 10 ; 12 ; 14$ \\
\hline • & An environment that fosters a positive creative energy, innovation, initiative, inspiration and resourcefulness & $3 ; 4 ; 7 ; 8 ; 10 ; 11 ; 14$ \\
\hline • & Authenticity and integrity / Ethical decision making & $4 ; 10 ; 11 ; 12 ; 14$ \\
\hline • & Involvement/ Empowerment / Participative management & $4 ; 12 ; 14$ \\
\hline • & Realisation of potential / Personal and professional growth / Opportunity to learn and grow & $3 ; 9 ; 10 ; 12 ; 14$ \\
\hline • & Self awareness & $3 ; 8 ; 10 ; 13 ; 16$ \\
\hline • & Community used as a metaphor & $6 ; 8 ; 12 ; 14$ \\
\hline • & A sense of connectedness to others & $6 ; 8 ; 12 ; 14$ \\
\hline • & Physical well-being / Positive, pleasant environment / Safety and security & $10 ; 12 ; 14$ \\
\hline • & Reward / Recognition / Acknowledgement/ Appreciation / Employees feel valued & $2 ; 4 ; 5 ; 6 ; 8 ; 12 ; 14$ \\
\hline • & Employees are principle centred & $4 ; 12 ; 14$ \\
\hline • & High levels of trust and trustworthiness & $4 ; 6,8,9,10 ; 11 ; 12 ; 14$ \\
\hline • & Employees feel listened to / Open communication/ Share information / Freedom of expression (no fear of reprisal) & $10 ; 12 ; 14$ \\
\hline • & An atmosphere of caring, understanding and concern for others / The Golden Rule & $10 ; 4 ; 14$ \\
\hline • & There is abundant legitimate power based on respect and loyalty (not upon fear or selfish motives) & $4 ; 14$ \\
\hline
\end{tabular}

Index of Authors

1) Aburdene (2005); 2) Ashmos and Duchon (2002); 3) Barrett (1998); 4) Covey (1989); 5) Gibbons (2002); 6) Howard and Wellbourn (2004); 7) Humphreys (2000); 8) Lamont (2002);

9) Marques, Dhiman and King (2005); 10) Miller (2003) 11) Mitroff and Denton (1999); 12) Parker (2005)13) Smith (2006); 14) Toms (1997); 15) Verrier (2002); 16) Zohar and Marshall (2004) 
For purposes of this study Smith's PiPL conceptualisation of spirituality will be used. According to Smith the essence or core of spirituality is beingness, i.e. where being finds expression. Associated with the core of beingness are some primary manifestations of the spirit that lend insight into what the spirit represents - they are not spirit, but spirit may be known by them. These core manifestations, in turn, find expression in certain observable peripheral manifestations.

Smith and Louw (2007, pp. 21-23) discuss the essence of spirituality as consisting of six elements:

1. Love - love finds expression in kindness, patience, helping, giving, caring, vitality, energy and vibration

2. Living in the NOW, the present - to be so utterly and completely present that no problem, no suffering, nothing that is not who you are in your essence can survive in you.

3. Silence - this is dropping one's ego.

4. Authenticity-BE who you are. Authenticity finds expression in character, integrity, simplicity, acceptance of self and of others and living in character instead of in persona. This is also about "straight talk" or caring confrontation.

5. Gratitude - not taking things for granted, thinking about what one has and developing an attitude of thankfulness.

6. Simplicity - demonstrated by living in the moment - with no idea of becoming this or that, responding to life, with spontaneity, total acceptance of the "such-ness" of life and with complete awareness.

From Smith and Louw (2007, p. 23) the following peripheral manifestations of spirituality are noted in Table 3: Smith (2006, p. 19) states that spirituality at work finds expression in manifestations such as:

- A pleasant, inviting work environment;

- Passion about one's work (job), experiencing work as a calling;

- Feeling energised by one's work;

- Finding meaning and purpose in work;

- Authentic expression (in one's work) and at the workplace;

- Feeling connected to those with whom one works, a sense of community;

- An atmosphere of trust;

- Continuous personal growth

- Feeling values, i.e. making a difference;

- Work that is recognised, rewarding and fulfilling,

- A culture of service

- A principle-centred approach finding expression in clarified values and a strong ethical (moral) code; and

- Inner well-being, i.e. harmony and balance in and between one's life dimensions.

It is beyond the scope of this study to discuss these core and peripheral manifestations in any further detail.

\section{Spirituality at work}

After studying the work of various authors on the subject of spirituality at work, the most frequently mentioned characteristics of spirituality at work are presented in Table 4.

For the purpose of this study, and of relevance to the branch, the seventeen most frequently mentioned characteristics of spirituality at work that will be measured are indicated in Table 5.

These seventeen characteristics were chosen as they are the most frequently cited characteristics (by the authors listed) and are the most relevant in terms of the bank's (and therefore the branch's) diagnostics and surveys used to measure employee satisfaction.

Linking values, behavioural guidelines and characteristics of spirituality at work

The eight values the bank has adopted have been linked to the seventeen characteristics of spirituality at work measured in this study. This can be extended to include some of the behavioural indicators of "living the value". In turn the behavioural indicators or guidelines (that are in fact manifestations of spirituality at work measured in this study) can be linked to questions in each of the two questionnaires used in this study (See Table 6).

\section{RESEARCH DESIGN}

\section{Research approach}

The research approach followed in this study is a quantitative field survey. Leedy and Ormrod (2001, p. 183) describe a survey research as research that involves acquiring information about one or more groups of people - perhaps about their characteristics, opinions, attitudes, or experiences - by asking them questions and tabulating their answers. The ultimate goal is to learn about a larger population by surveying a sample of that population.

Reduced to its basic elements a survey is quite simple in design: The researcher poses a series of questions to willing participants, summarises their responses and then draws inferences about a particular population from the response of the sample (Leedy \& Ormrod, 2001, pp. 183-184). Survey research typically employs a face-to-face interview, a telephone interview, or a written questionnaire (Leedy \& Ormrod, 2001, p. 184).

\section{Participants}

Gay and Airasian (in Leedy \& Ormrod, 2001, p. 207) have offered the following guidelines for selecting a sample size:

1. For small populations (fewer than 100 people), there is little point in sampling. Survey the entire population.

2. If the population size is around $500,50 \%$ of the population should be sampled.

3. If the population size is around $1500,20 \%$ should be sampled.

4. Beyond a certain point (about 5000 units or more), the population size is almost irrelevant, and a sample size of 400 should be adequate.

As the staff compliment of the branch is 93 employees, the entire population was surveyed. This specific branch was chosen for this study as it has been identified as a "pilot site" and is within the researchers' mandate in terms of assessing

\section{TABLE 5
Characteristics of spirituality at work measured in this study}

- Meaningful and challenging work. A sense of vocation. Making a meaningful
contribution.
- Congruence between personal and corporate values.
- Employees share a common vision, mission and goals.
- Drawing on and a tolerance for diversity of people and differences.
- Teamwork and team spirit.
- An environment that fosters a positive creative energy, innovation, initiative,
inspiration and resourcefulness.
- Authenticity, integrity and ethical decision making.
- Involvement, empowerment and participative management.
- Realisation of potential, personal and professional growth. Opportunities to
learn and develop.
- Employees experience a sense of community.
- A sense of connectedness to others.
- Physical well-being, positive and pleasant environment, safety and security.
- Appropriate reward and recognition, acknowledgement and appreciation.
Employees feel valued.
- High levels of trust and trustworthiness.
- Employees feel listened to, open communication and sharing of information.
Freedom of expression without fear of reprisal.
- An atmosphere of caring, understanding, and concern for others. The Golden
Rule.
- There is abundant legitimate power based on respect and loyalty (not upon
fear and selfish motives).


employee satisfaction and developing appropriate interventions to enhance employee satisfaction.

\section{Measuring instrument}

This study made use of two written questionnaires. The base of these questionnaires was developed by Smith and adapted by the researcher to include the relevant characteristics of spirituality at work that this study seeks to measure. The first questionnaire consists of 21 statements that characterise a spiritual workplace, and asks respondents to rate the extent to which each statement is characteristic (descriptive) of the branch environment or workplace. The second questionnaire tests if respondents are spiritually fulfilled at work.

The questions from both questionnaires have been linked to the characteristics of spirituality at work as measured by this study. Table 7 indicates these links.

\section{Research Procedure}

Senior Management approval at the organisation was obtained for the study. The objective and relevance of the survey, as well as instructions for completing the two questionnaires were discussed at a monthly staff meeting. At this meeting the questionnaires were handed out to the staff by the researcher. Branch employees were asked to take time after the meeting to complete the questionnaires. The researcher who was present at the staff meeting collected the completed questionnaires from the respondents. This process gave respondents some assurance that branch management would not see their responses. To further ensure confidentiality and enhance participation and reliability, the study was conducted anonymously.

\section{Statistical analysis}

In total, 70 of the 93 staff members completed the questionnaire. This equates to $75 \%$ of the population. The data was analysed in two phases. The first phase analysed the basic descriptive statistics in respect of responses to the two questionnaires, reliability analysis using Cronbach's Alpha, paired t-tests and paired sample correlation. The second phase tested for significant differences across new categories of demographical dimensions using analysis of variance (ANOVA) tests. The basic descriptives of the respondents are presented in Table 8.

TABLE 6

Linking values, behaviours and characteristics of spirituality at work

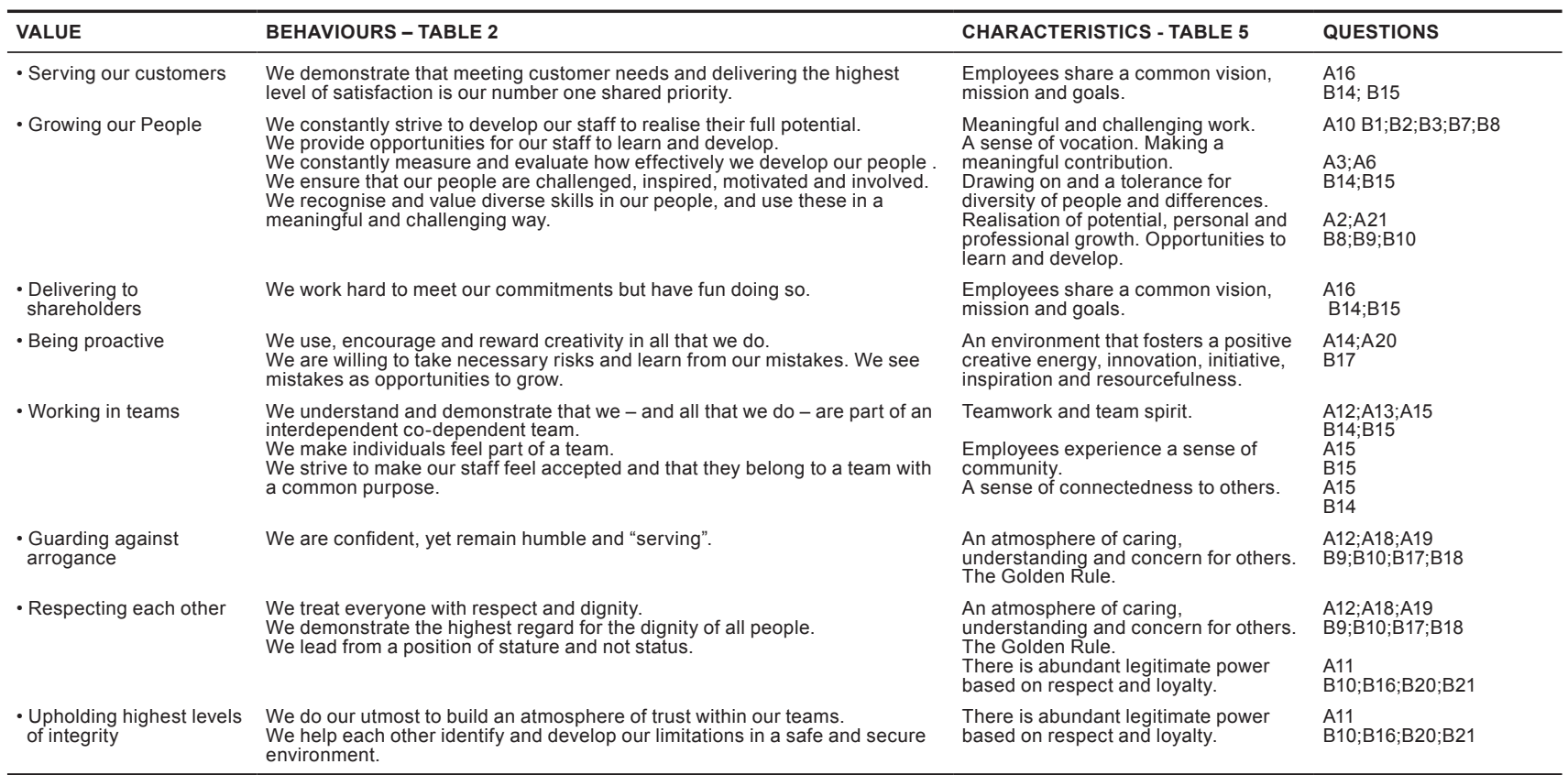

TABLE 7

Linking characteristics of spirituality to questions

\begin{tabular}{|c|c|c|c|}
\hline \multicolumn{2}{|c|}{ CHARACTERISTIC } & \multirow{2}{*}{$\frac{A}{10}$} & \multirow{2}{*}{$\frac{\text { B }}{1 ; 2 ; 3 ; 7 ; 8}$} \\
\hline$\cdot$ & Meaningful and challenging work. A sense of vocation. Making a meaningful contribution & & \\
\hline • & Congruence between personal and corporate values & 16 & $4 ; 21$ \\
\hline • & Employees share a common vision, mission and goals & 16 & $14 ; 15$ \\
\hline • & Drawing on and a tolerance for diversity of people and differences & $3 ; 6$ & $14 ; 15$ \\
\hline • & Teamwork and team spirit & $12 ; 13 ; 15$ & $14 ; 15$ \\
\hline • & An environment that fosters a positive creative energy, innovation, initiative, inspiration and resourcefulness & $14 ; 20$ & 17 \\
\hline • & Authenticity, integrity and ethical decision making & $1 ; 19$ & $10 ; 20 ; 21$ \\
\hline • & Involvement, empowerment and participative management & $4 ; 5$ & 5 \\
\hline • & Realisation of potential, personal and professional growth. Opportunities to learn and develop & $2 ; 21$ & $8 ; 9 ; 10$ \\
\hline • & Employees experience a sense of community & 15 & 15 \\
\hline • & A sense of connectedness to others & 15 & 14 \\
\hline • & Physical well-being, positive and pleasant environment, safety and security & $7 ; 8$ & 6 \\
\hline • & Appropriate reward and recognition, acknowledgement, appreciation. Employees feel valued & $9 ; 10$ & $11 ; 12 ; 13 ; 19$ \\
\hline • & High levels of trust and trustworthiness & $1 ; 19$ & $10 ; 16$ \\
\hline • & Employees feel listened to. Open communication. Sharing of information. Freedom of expression & $11 ; 17$ & 12 \\
\hline • & Atmosphere of caring, understanding, and concern for others. The Golden Rule & $12 ; 18 ; 19$ & $9 ; 10 ; 17 ; 18$ \\
\hline - & Abundant legitimate power based on respect and loyalty - not upon fear and selfish motives & 11 & $10 ; 16 ; 20 ; 21$ \\
\hline
\end{tabular}




\section{RESULTS}

Result of the Spirituality at Work Questionnaire - Questionnaire A

Using 21 statements, questionnaire A was aimed at identifying the presence (or lack thereof) of the 17 characteristics used in this study that are descriptive of spirituality at work. Respondents were asked to rate the extent to which the statement is characteristic of their workplace (the branch surveyed). The results are shown in Table 9 .

The statistics in respect of the responses to Questionnaire A were reviewed and are shown in Table 10. Questions A2; A14 and A20 all have a mean score of $>4$. Question A2 - Employees have opportunities to learn and develop - linked to the value "Growing our People" scored the highest mean score of 4.03 This is significant as this has been identified by the bank as a strategic imperative and key competitive advantage.

\section{Results of the Spiritual Fulfilment at Work Questionnaire - Questionnaire B}

Using 21 statements, questionnaire B was aimed at assessing the extent of spiritual fulfilment at work of the employees within the branch. The results of questionnaire B are shown in Table 11.

The results of questionnaire B were analysed and the statistics are shown in Table 12. The lowest mean score is in respect of question B19 relating to "appropriate salary for work done". The three highest mean scores are in respect of B4 "I am truly committed to my work"; B7 "I feel that I make a valuable contribution in my work"; and B9 "I feel that my leadership is committed to my personal and professional growth". The value "growing our people" as measured by B19 is in the top three highest mean scores.

TABLE 8

Basic descriptive of respondents

\begin{tabular}{lll}
\hline DESCRIPTIVE & RESPONDENTS & PERCENTAGE \\
\hline
\end{tabular}

\begin{tabular}{lrr}
\hline Age & 37 & \\
$20-30$ & 10 & 52.9 \\
$31-35$ & 8 & 14.3 \\
$36-40$ & 7 & 11.4 \\
$41-49$ & 7 & 10.0 \\
$50+$ & 69 & 10.0 \\
Total & 1 & 98.6 \\
Missing & & 1.4 \\
Ethnicity & 25 & \\
African & 11 & 35.7 \\
Indian & 9 & 15.7 \\
Coloured & 9 & 12.9 \\
White & 25 & 35.7 \\
Total & 70 & 100.0 \\
Tenure & & \\
$<3$ & 20 & 28.6 \\
$3-5$ & 9 & 12.9 \\
$5-10$ & 14 & 20.0 \\
$>10$ & 23 & 32.9 \\
Total & 66 & 94.3 \\
Missing & 4 & 5.7 \\
Job Level & & \\
General Staff & 60 & 85.7 \\
Managers & 8 & 11.4 \\
Total & & 97.1 \\
Missing & 2 [E J4] & 2.9 \\
\hline \multicolumn{1}{c}{ DESCRIPTIVE } & RESPONDENTS & PERCENTAGE \\
\hline
\end{tabular}

\begin{tabular}{lcc}
\hline \multicolumn{1}{c}{ DESCRIPTIVE } & RESPONDENTS & PERCENTAGE \\
\hline Function & & \\
Support & 32 & 45.7 \\
Finance & 6 & 8.6 \\
Sales & 21 & 30.0 \\
Admin & 1 & 1.4 \\
Total & 60 & 85.7 \\
Missing & 10 & 14.3 \\
Years in Job Level & & \\
1-3 & 49 & 70.0 \\
$3-10$ & 11 & 15.7 \\
$>10$ & 4 & 5.7 \\
Total & 64 & 91.4 \\
Missing & 6 & $8.6[\mathrm{E} \mathrm{J1}]$ \\
Years in the branch & & \\
1-3 & 37 & 52.8 \\
$3-10$ & 20 & 28.6 \\
$>10$ & 8 & 11.4 \\
Total & 65 & 92.9 \\
Missing & $5[\mathrm{E} \mathrm{J2}]$ & $7.1[\mathrm{E} \mathrm{J3}]$ \\
\hline
\end{tabular}

The results indicate that the majority of the respondents found that all of the 17 characteristics of spirituality at work measured in this study are present in the branch "very often" or "all the time". These results are shown in Table 13.

The results of Questionnaire B - Spiritual Fulfilment at Work - indicate that the majority of the respondents find spiritual fulfilment at work (in the branch) "often" or "almost always". These results are shown in Table 14

The only exception is in respect of question B19 that partly measures the characteristic "reward and recognition, and acknowledgement and appreciation". Question 19 in questionnaire B is "I feel my salary is reasonable (appropriate) for the work that I do." Only $27.1 \%$ of the respondents felt this was true "often" and 14.3\% felt it true "almost always". This question received the highest percentage in the rating scale "never" with $12.9 \%$ of respondents saying that their salary is not (never) reasonable or appropriate for the work that they do.

Based on the link made between characteristics of spirituality at work, the bank's values and associated behavioural indicators of "living the values", the results indicate that employees in the branch see and experience evidence of the values at work in the branch.

Whilst all the values are equally important, the bank has acknowledged that talent management is and will continue to be a strategic imperative and a key competitive advantage. To this end the results in respect of the value "growing our people" and the corresponding characteristics of spirituality at work, will be elaborated on.

The value "growing our people" has been linked to the following characteristics of spirituality at work:

1. Meaningful and challenging work. A sense of vocation. Making a meaningful contribution. (Questions A10; B1; B2; B3;B7 and B8)

2. Drawing on and a tolerance for diversity of people and differences. (Questions A3; A6; B14 and B15)

3. Realisation of potential, personal and professional growth Opportunities to grow and develop. (Questions A2; A21; B8; B9 and B10)

The statistics in respect of the questions dealing with these three characteristics are shown in Table 15. Paired t-test results for the questions dealing with these characteristics are shown in Table 16 and Table 17.

In all three cases there are no significant differences between how respondents answered questions from questionnaire $\mathrm{A}$ and questions from questionnaire B that deal with the same characteristic of spirituality at work and the corresponding value "growing our people". In respect of the answers from questionnaires $\mathrm{A}$ and $\mathrm{B}$ there is moderate correlation (.479) for pair 1, and strong correlation (.661 and .575) for pair 2 and pair 3 respectively - as shown in Table 16.

Reliability analysis showed the reliability statistics as shown in Table 18. Reliability was found in all five sets of questions where Cronbach's Alpha was found to be greater than 0.7. The results show that the employees in the branch believe the following characteristics of spirituality at work - 1) Meaningful and challenging work, 2) Drawing on and a tolerance for diversity of people and differences and 3) Realisation of potential, personal and professional growth. Opportunities to grow and develop are present in the branch and the value "growing our people" is alive and well. 
TABLE 9

Results of questionnaire A: A spiritual workplace

\begin{tabular}{|c|c|c|c|c|c|c|c|}
\hline $\begin{array}{l}\text { CHARACTERISTIC OF SPIRITUALITY AT WORK } \\
\text { STATEMENT DESCRIBING YOUR WORKPLACE }\end{array}$ & & NOT AT ALL & $\begin{array}{l}\text { VERY } \\
\text { SELDOM }\end{array}$ & SOMETIMES & $\begin{array}{l}\text { VERY } \\
\text { OFTEN }\end{array}$ & $\begin{array}{l}\text { ALL OF } \\
\text { TIME }\end{array}$ & NO RESPONSE \\
\hline \multirow[t]{2}{*}{ A1: There is an atmosphere of trust } & Count & 1 & 8 & 19 & 29 & 12 & 1 \\
\hline & $\%$ & $1.4 \%$ & $11.4 \%$ & $27.1 \%$ & $41.4 \%$ & $17.1 \%$ & $1.4 \%$ \\
\hline \multirow{2}{*}{$\begin{array}{l}\text { A2: Employees have opportunities to learn and develop as } \\
\text { people }\end{array}$} & Count & & 4 & 13 & 29 & 23 & 1 \\
\hline & $\%$ & & $5.7 \%$ & $18.6 \%$ & $41.4 \%$ & $32.9 \%$ & $1.4 \%$ \\
\hline \multirow[t]{2}{*}{ A3: There is tolerance for diversity of people and differences } & Count & & 5 & 19 & 24 & 21 & 1 \\
\hline & $\%$ & & $7.1 \%$ & $27.1 \%$ & $34.3 \%$ & $30.0 \%$ & $1.4 \%$ \\
\hline \multirow{2}{*}{$\begin{array}{l}\text { A4: Employees feel empowered and involved in the managing } \\
\text { of the business }\end{array}$} & Count & 1 & 4 & 16 & 32 & 15 & 2 \\
\hline & $\%$ & $1.4 \%$ & $5.7 \%$ & $22.9 \%$ & $45.7 \%$ & $21.4 \%$ & $2.9 \%$ \\
\hline \multirow[t]{2}{*}{ A5: There is a participative management style } & Count & 1 & 5 & 12 & 29 & 21 & 2 \\
\hline & $\%$ & $1.4 \%$ & $7.1 \%$ & $17.1 \%$ & $41.4 \%$ & $30.0 \%$ & $2.9 \%$ \\
\hline \multirow{2}{*}{$\begin{array}{l}\text { A6: Differences in culture, personalities and skills are } \\
\text { respected, valued and used }\end{array}$} & Count & 1 & 4 & 17 & 26 & 22 & \\
\hline & $\%$ & $1.4 \%$ & $5.7 \%$ & $24.3 \%$ & $37.1 \%$ & $31.4 \%$ & \\
\hline \multirow{2}{*}{$\begin{array}{l}\text { A7: The workplace is a safe and pleasant environment } \\
\text { generating a positive pleasant atmosphere }\end{array}$} & Count & 2 & 5 & 17 & 33 & 13 & \\
\hline & $\%$ & $2.9 \%$ & $7.1 \%$ & $24.3 \%$ & $47.1 \%$ & $18.6 \%$ & \\
\hline \multirow{2}{*}{$\begin{array}{l}\text { A8: Employees experience job security - they do not fear they } \\
\text { will be retrenched unexpectedly }\end{array}$} & Count & 2 & 3 & 20 & 30 & 15 & \\
\hline & $\%$ & $2.9 \%$ & $4.3 \%$ & $28.6 \%$ & $42.9 \%$ & $21.4 \%$ & \\
\hline \multirow{2}{*}{$\begin{array}{l}\text { A9: Employees feel recognised and acknowledged for work } \\
\text { done }\end{array}$} & Count & 1 & 6 & 16 & 26 & 20 & 1 \\
\hline & $\%$ & $1.4 \%$ & $8.6 \%$ & $22.9 \%$ & $37.1 \%$ & $28.6 \%$ & $1.4 \%$ \\
\hline \multirow{2}{*}{$\begin{array}{l}\text { A10: Employees feel valued as employees and experience a } \\
\text { sense of meaningful contribution to the business }\end{array}$} & Count & & 6 & 17 & 31 & 16 & \\
\hline & $\%$ & & $8.6 \%$ & $24.3 \%$ & $44.3 \%$ & $22.9 \%$ & \\
\hline \multirow{2}{*}{$\begin{array}{l}\text { A11: There is a culture of open and honest communication and } \\
\text { information sharing without fear of reprisal }\end{array}$} & Count & 1 & 8 & 21 & 23 & 16 & 1 \\
\hline & $\%$ & $1.4 \%$ & $11.4 \%$ & $30.0 \%$ & $32.9 \%$ & $22.9 \%$ & $1.4 \%$ \\
\hline \multirow[t]{2}{*}{ A12: Employees are appreciative of and thankful for each other } & Count & & 4 & 19 & 26 & 19 & 2 \\
\hline & $\%$ & & $5.7 \%$ & $27.1 \%$ & $37.1 \%$ & $27.1 \%$ & $2.9 \%$ \\
\hline \multirow{2}{*}{$\begin{array}{l}\text { A13: There is strong teamwork in which employees count on } \\
\text { one another for help and support }\end{array}$} & Count & 1 & 5 & 13 & 31 & 18 & 2 \\
\hline & $\%$ & $1.4 \%$ & $7.1 \%$ & $18.6 \%$ & $44.3 \%$ & $25.7 \%$ & $2.9 \%$ \\
\hline \multirow[t]{2}{*}{ A14: There is energy, fun and creativity in the workplace } & Count & & 5 & 13 & 27 & 25 & \\
\hline & $\%$ & & $7.1 \%$ & $18.6 \%$ & $38.6 \%$ & $35.7 \%$ & \\
\hline \multirow{2}{*}{$\begin{array}{l}\text { A15: There is a sense of a community and connectedness } \\
\text { amongst the staff - employees feel accepted / belong }\end{array}$} & Count & & 4 & 20 & 27 & 19 & \\
\hline & $\%$ & & $5.7 \%$ & $28.6 \%$ & $38.6 \%$ & $27.1 \%$ & \\
\hline \multirow{2}{*}{$\begin{array}{l}\text { A16: There is a sense of shared values and common purpose } \\
\text { that inspires and motivates employees }\end{array}$} & Count & & 6 & 20 & 26 & 18 & \\
\hline & $\%$ & & $8.6 \%$ & $28.6 \%$ & $37.1 \%$ & $25.7 \%$ & \\
\hline \multirow[t]{2}{*}{ A17: Employees feel listened to } & Count & 2 & 2 & 28 & 26 & 12 & \\
\hline & $\%$ & $2.9 \%$ & $2.9 \%$ & $40.0 \%$ & $37.1 \%$ & $17.1 \%$ & \\
\hline \multirow[t]{2}{*}{ A18: The leadership cares about the employees } & Count & & 5 & 20 & 26 & 19 & \\
\hline & $\%$ & & $7.1 \%$ & $28.6 \%$ & $37.1 \%$ & $27.1 \%$ & \\
\hline \multirow[t]{2}{*}{ A19: Justice, fairness and Integrity are the order of the day } & Count & 1 & 3 & 26 & 24 & 16 & \\
\hline & $\%$ & $1.4 \%$ & $4.3 \%$ & $37.1 \%$ & $34.3 \%$ & $22.9 \%$ & \\
\hline \multirow[t]{2}{*}{ A20: There is a service orientation in the workplace } & Count & & 3 & 12 & 35 & 20 & \\
\hline & $\%$ & & $4.3 \%$ & $17.1 \%$ & $50.0 \%$ & $28.6 \%$ & \\
\hline \multirow[t]{2}{*}{ A21: Employees are competent and have the required skills } & Count & & 4 & 18 & 36 & 11 & 1 \\
\hline & $\%$ & & $5.7 \%$ & $25.7 \%$ & $51.4 \%$ & $15.7 \%$ & $1.4 \%$ \\
\hline
\end{tabular}

TABLE 10

Statistics of Questionnaire A

\begin{tabular}{|c|c|c|c|c|}
\hline QUESTION & VALID & MISSING & MEAN & STD DEVIATION \\
\hline A1: There is an atmosphere of trust & 69 & 1 & 3.62 & .956 \\
\hline A2: Employees have opportunities to learn and develop as people & 69 & 1 & 4.03 & .874 \\
\hline A3: There is tolerance for diversity of people and differences & 69 & 1 & 3.88 & .932 \\
\hline A4: Employees feel empowered and involved in the managing of the business & 68 & 2 & 3.82 & .897 \\
\hline A5: There is a participative management style & 68 & 2 & 3.94 & .960 \\
\hline A6: Differences in culture, personalities and skills are respected, valued and used & 70 & 0 & 3.91 & .959 \\
\hline A7: The workplace is a safe and pleasant environment generating a positive pleasant atmosphere & 70 & 0 & 3.71 & .950 \\
\hline A8: Employees experience job security - they do not fear they will be retrenched unexpectedly & 70 & 0 & 3.76 & .939 \\
\hline A9: Employees feel recognised and acknowledged for work done & 69 & 1 & 3.84 & .994 \\
\hline A10: Employees feel valued as employees and experience a sense of meaningful contribution to the business & 70 & 0 & 3.81 & .889 \\
\hline A11: There is a culture of open and honest communication and information sharing without fear of reprisal & 69 & 1 & 3.65 & 1.012 \\
\hline A12: Employees are appreciative of, and thankful for each other & 68 & 2 & 3.88 & .890 \\
\hline A13: There is strong teamwork in which employees count on one another for help and support & 68 & 2 & 3.88 & .939 \\
\hline A14: There is energy, fun and creativity in the workplace & 70 & 0 & 4.03 & .916 \\
\hline A15: There is a sense of a community and connectedness amongst the staff - employees feel accepted / belong & 70 & 0 & 3.87 & .883 \\
\hline A16: There is a sense of shared values and common purpose that inspires and motivates employees & 70 & 0 & 3.80 & .926 \\
\hline A17: Employees feel listened to & 70 & 0 & 3.63 & .904 \\
\hline A18: The leadership cares about the employees & 70 & 0 & 3.84 & .911 \\
\hline A19: Justice, fairness and integrity are the order of the day & 70 & 0 & 3.73 & .916 \\
\hline A20: There is a service orientation in the workplace & 70 & 0 & 4.03 & .798 \\
\hline A21: Employees are competent and have the required skills & 69 & 1 & 3.78 & .783 \\
\hline
\end{tabular}


TABLE 11

Results of Questionnaire B

\begin{tabular}{|c|c|c|c|c|c|c|c|}
\hline QUESTION & & NEVER & OCCASIONALLY & SOMETIMES & OFTEN & $\begin{array}{l}\text { ALMOST } \\
\text { ALWAYS }\end{array}$ & NO RESPONSE \\
\hline \multirow{2}{*}{$\begin{array}{l}\text { B1: I experience a sense of meaningfulness and } \\
\text { fulfilment at work }\end{array}$} & Count & 2 & 3 & 19 & 24 & 22 & \\
\hline & $\%$ & $2.9 \%$ & $4.3 \%$ & $27.1 \%$ & $34.3 \%$ & $31.4 \%$ & \\
\hline \multirow[t]{2}{*}{ B2: I feel energised in my work - I enjoy what I do } & Count & 2 & 3 & 17 & 24 & 24 & \\
\hline & $\%$ & $2.9 \%$ & $4.3 \%$ & $24.3 \%$ & $34.3 \%$ & $34.3 \%$ & \\
\hline \multirow[t]{2}{*}{ B3: I am enthusiastic about my work } & Count & 2 & 3 & 15 & 23 & 27 & \\
\hline & $\%$ & $2.9 \%$ & $4.3 \%$ & $21.4 \%$ & $32.9 \%$ & $38.6 \%$ & \\
\hline \multirow[t]{2}{*}{ B4: I am truly committed to my work } & Count & & 1 & 8 & 24 & 37 & \\
\hline & $\%$ & & $1.4 \%$ & $11.4 \%$ & $34.3 \%$ & $52.9 \%$ & \\
\hline \multirow[t]{2}{*}{ B5: I feel empowered in my work } & Count & 1 & 2 & 16 & 25 & 25 & 1 \\
\hline & $\%$ & $1.4 \%$ & $2.9 \%$ & $22.9 \%$ & $35.7 \%$ & $35.7 \%$ & $1.4 \%$ \\
\hline \multirow{2}{*}{$\begin{array}{l}\text { B6: I experience job security - not to be retrenched } \\
\text { unexpectedly }\end{array}$} & Count & 1 & 8 & 17 & 22 & 22 & \\
\hline & $\%$ & $1.4 \%$ & $11.4 \%$ & $24.3 \%$ & $31.4 \%$ & $31.4 \%$ & \\
\hline \multirow{2}{*}{$\begin{array}{l}\text { B7: I feel that I make a valuable contribution in my } \\
\text { work }\end{array}$} & Count & & 1 & 9 & 20 & 39 & 1 \\
\hline & $\%$ & & $1.4 \%$ & $12.9 \%$ & $28.6 \%$ & $55.7 \%$ & $1.4 \%$ \\
\hline \multirow{2}{*}{$\begin{array}{l}\text { B8: I feel that my potential is recognised and utilised } \\
\text { effectively at work }\end{array}$} & Count & 1 & 4 & 15 & 27 & 20 & 3 \\
\hline & $\%$ & $1.4 \%$ & $5.7 \%$ & $21.4 \%$ & $38.6 \%$ & $28.6 \%$ & $4.3 \%$ \\
\hline \multirow{2}{*}{$\begin{array}{l}\text { B9: I feel that my leadership is committed to my } \\
\text { personal and professional growth }\end{array}$} & Count & & 2 & 17 & 21 & 29 & 1 \\
\hline & $\%$ & & $2.9 \%$ & $24.3 \%$ & $30.0 \%$ & $41.4 \%$ & $1.4 \%$ \\
\hline \multirow{2}{*}{$\begin{array}{l}\text { B10: I am open about my weaknesses and willing to } \\
\text { expose these at work }\end{array}$} & Count & & 3 & 15 & 31 & 21 & \\
\hline & $\%$ & & $4.3 \%$ & $21.4 \%$ & $44.3 \%$ & $30.0 \%$ & \\
\hline \multirow{2}{*}{$\begin{array}{l}\text { B11: When I achieve something at work I feel it is } \\
\text { recognised and appreciated }\end{array}$} & Count & & 4 & 21 & 21 & 24 & \\
\hline & $\%$ & & $5.7 \%$ & $30.0 \%$ & $30.0 \%$ & $34.3 \%$ & \\
\hline \multirow{2}{*}{$\begin{array}{l}\text { B12: I can express myself freely in my workplace } \\
\text { without fear of reprisal }\end{array}$} & Count & & 6 & 26 & 19 & 19 & \\
\hline & $\%$ & & $8.6 \%$ & $37.1 \%$ & $27.1 \%$ & $27.1 \%$ & \\
\hline \multirow[t]{2}{*}{ B13: I am being acknowledged for work well done } & Count & & 2 & 18 & 24 & 25 & 1 \\
\hline & $\%$ & & $2.9 \%$ & $25.7 \%$ & $34.3 \%$ & $35.7 \%$ & $1.4 \%$ \\
\hline \multirow{2}{*}{$\begin{array}{l}\text { B14: I feel connected to or part of a bigger picture } \\
\text { (vision) of the organisation }\end{array}$} & Count & 2 & 4 & 17 & 23 & 24 & \\
\hline & $\%$ & $2.9 \%$ & $5.7 \%$ & $24.3 \%$ & $32.9 \%$ & $34.3 \%$ & \\
\hline \multirow{2}{*}{$\begin{array}{l}\text { B15: I experience a sense of community, a common } \\
\text { bond between me and my colleagues }\end{array}$} & Count & & 4 & 15 & 26 & 25 & \\
\hline & $\%$ & & $5.7 \%$ & $21.4 \%$ & $37.1 \%$ & $35.7 \%$ & \\
\hline \multirow{2}{*}{$\begin{array}{l}\text { B16: An atmosphere of mutual trust exists in my work } \\
\text { team }\end{array}$} & Count & 1 & 6 & 18 & 22 & 17 & 6 \\
\hline & $\%$ & $1.4 \%$ & $8.6 \%$ & $25.7 \%$ & $31.4 \%$ & $24.3 \%$ & $8.6 \%$ \\
\hline \multirow[t]{2}{*}{ B17: My workplace culture is service orientated } & Count & & 4 & 12 & 30 & 24 & \\
\hline & $\%$ & & $5.7 \%$ & $17.1 \%$ & $42.9 \%$ & $34.3 \%$ & \\
\hline \multirow{2}{*}{$\begin{array}{l}\text { B18: I feel that people in the workplace are supportive } \\
\text { and help each other when needed }\end{array}$} & Count & & 4 & 17 & 28 & 20 & 1 \\
\hline & $\%$ & & $5.7 \%$ & $24.3 \%$ & $40.0 \%$ & $28.6 \%$ & $1.4 \%$ \\
\hline \multirow{2}{*}{$\begin{array}{l}\text { B19: I feel my salary is reasonable (appropriate) for the } \\
\text { work that I do }\end{array}$} & Count & 9 & 15 & 17 & 19 & 10 & \\
\hline & $\%$ & $12.9 \%$ & $21.4 \%$ & $24.3 \%$ & $27.1 \%$ & $14.3 \%$ & \\
\hline \multirow[t]{2}{*}{ B20: I am treated with dignity and respect } & Count & & 6 & 14 & 28 & 22 & \\
\hline & $\%$ & & $8.6 \%$ & $20.0 \%$ & $40.0 \%$ & $31.4 \%$ & \\
\hline \multirow[t]{2}{*}{ B21: I am able to be my "true self" at work } & Count & & 4 & 16 & 22 & 28 & \\
\hline & $\%$ & & $5.7 \%$ & $22.9 \%$ & $31.4 \%$ & $40.0 \%$ & \\
\hline
\end{tabular}

\section{Demographical differences}

The results were analysed using ANOVA to determine if there are any significant differences in the responses between demographical groupings. The following demographical groupings were analysed and compared:

1. Age Groups

a. 20 -35 years

b. 36 years and older

2. Ethnic Groups

a. African

b. White

c. Indian

d. Coloured

3. Job Levels

a. Managerial

b. General staff

4. Years of service differences - tenure

a. $<3$ years of service

b. 3-10 years of service

c. $>10$ years of service

It is beyond the scope of this study to report and interpret these findings in any detail, and therefore these results are not presented. It should be noted, however, that there are no significant differences over age groups and job levels, but that there are a few significant differences over ethnicity and tenure. Given the complexity of this analysis these findings are not presented and elaborated on, but should be considered as an element for further research.

\section{DISCUSSION}

\section{Interviews with branch managers}

The researcher discussed the results of the survey with branch management and two workshops were held (23 February 2007 and 18 April 2007) to discuss possible explanations for the results obtained. Whilst the branch surveyed is part of the bank's broader branch network and as such follows certain mandatory branch operating policies, procedures and operating practices, the branch surveyed also deploys various interventions and practices that are unique to this branch and are the initiative of the branch leadership. Some of these initiatives that might be "causal" and that may have contributed to the results of the survey are the following:

- Frequent team building

- A mentoring programme

- Each staff member is part of a "buddy system"

- An extensive "on boarding" programme for new recruits 
TABLE 12

Statistics of Questionnaire B

\begin{tabular}{|c|c|c|c|c|}
\hline QUESTION & VALID & MISSING & MEAN & $\begin{array}{l}\text { STD. } \\
\text { DEVIATION }\end{array}$ \\
\hline $\begin{array}{l}\text { B1: I experience a sense of } \\
\text { meaningfulness and fulfilment at } \\
\text { work }\end{array}$ & 70 & 0 & 3.87 & 1.006 \\
\hline $\begin{array}{l}\text { B2: I feel energised in my work - I } \\
\text { enjoy what I do }\end{array}$ & 70 & 0 & 3.93 & 1.012 \\
\hline $\begin{array}{l}\text { B3: I am enthusiastic about my } \\
\text { work }\end{array}$ & 70 & 0 & 4.00 & 1.022 \\
\hline B4: I am truly committed to my work & 70 & 0 & 4.39 & .748 \\
\hline B5: I feel empowered in my work & 69 & 1 & 4.03 & .923 \\
\hline $\begin{array}{l}\text { B6: I experience job security - not } \\
\text { to be retrenched unexpectedly }\end{array}$ & 70 & 0 & 3.80 & 1.058 \\
\hline $\begin{array}{l}\text { B7: I feel that I make a valuable } \\
\text { contribution in my work }\end{array}$ & 69 & 1 & 4.41 & .773 \\
\hline $\begin{array}{l}\text { B8: I feel that my potential is } \\
\text { recognised and utilised effectively } \\
\text { at work }\end{array}$ & 67 & 3 & 3.91 & .949 \\
\hline $\begin{array}{l}\text { B9: I feel that my leadership is } \\
\text { committed to my personal and } \\
\text { professional growth }\end{array}$ & 69 & 1 & 4.12 & .883 \\
\hline $\begin{array}{l}\text { B10: I am open about my } \\
\text { weaknesses and willing to expose } \\
\text { these at work }\end{array}$ & 70 & 0 & 4.00 & .834 \\
\hline $\begin{array}{l}\text { B11: When I achieve something } \\
\text { at work I feel it is recognised and } \\
\text { appreciated }\end{array}$ & 70 & 0 & 3.93 & .937 \\
\hline $\begin{array}{l}\text { B12: I can express myself freely } \\
\text { in my workplace without fear of } \\
\text { reprisal }\end{array}$ & 70 & 0 & 3.73 & .962 \\
\hline $\begin{array}{l}\text { B13: I am being acknowledged for } \\
\text { work well done }\end{array}$ & 69 & 1 & 4.04 & .865 \\
\hline $\begin{array}{l}\text { B14: I feel connected to or part } \\
\text { of a bigger picture (vision) of the } \\
\text { organisation }\end{array}$ & 70 & 0 & 3.90 & 1.038 \\
\hline $\begin{array}{l}\text { B15: I experience a sense of } \\
\text { community, a common bond } \\
\text { between me and my colleagues }\end{array}$ & 70 & 0 & 4.03 & .900 \\
\hline $\begin{array}{l}\text { B16: An atmosphere of mutual trust } \\
\text { exists in my work team }\end{array}$ & 64 & 6 & 3.75 & 1.008 \\
\hline $\begin{array}{l}\text { B17: My workplace culture is } \\
\text { service orientated }\end{array}$ & 70 & 0 & 4.06 & .866 \\
\hline $\begin{array}{l}\text { B18: I feel that people in the } \\
\text { workplace are supportive and help } \\
\text { each other when needed }\end{array}$ & 69 & 1 & 3.93 & .880 \\
\hline $\begin{array}{l}\text { B19: I feel my salary is reasonable } \\
\text { (appropriate) for the work that I do }\end{array}$ & 70 & 0 & 3.09 & 1.260 \\
\hline $\begin{array}{l}\text { B20: I am treated with dignity and } \\
\text { respect }\end{array}$ & 70 & 0 & 3.94 & .931 \\
\hline $\begin{array}{l}\text { B21: I am able to be my "true self" } \\
\text { at work }\end{array}$ & 70 & 0 & 4.06 & .931 \\
\hline
\end{tabular}

- Monthly competitions around themes such as "best idea"; "discovery"; "share and tell", and others

- Actively soliciting feedback from internal and external clients

- A "values person" competition, where every month there is a substantial prize for the staff member who is seen to be demonstrating the behaviour/s of "living the values". Staff are encouraged to "catch their colleagues" demonstrating such behaviours.

- Every staff member in the branch has a personal development plan that is reviewed quarterly by the line manager, the mentor, and, in some cases, an executive coach.

These initiatives should be investigated in more detail to determine the impact they may have on making the branch a spiritual workplace as measured by the characteristics of spirituality at work measured in this survey. This will be noted in recommendations for further research.

\section{Conclusions and recommendations}

The objective of this study was to investigate whether or not this branch is a spiritual workplace with employees in the branch living the values of the bank and whether or not employees in the branch are spiritually fulfilled at work. The results have shown that the branch - as a workplace - is a spiritual workplace as characterised by the seventeen indicators measured in this study. Employees in the branch are "living the values". They are demonstrating the behaviours that indicate they are living the values. Strategically the bank has identified talent management as a critical imperative and key competitive advantage.

In terms of the value "growing our people" and the corresponding three characteristics of spirituality at work, namely: 1) meaningful and challenging work; 2) drawing on and a tolerance for diversity of people and differences, and 3) realisation of potential, personal and professional growth and opportunities to grow and develop, the results indicate that these characteristics are present and employees are living this value.

Interviews with branch management revealed certain "in branch" initiatives that may be contributing to making the branch a spiritual workplace. It is recommended that a project team be initiated, consisting of human resources as well as learning and development practitioners to work together with

Respondents who believe characteristics are present "very often" and "all the time"

\begin{tabular}{|c|c|c|}
\hline CHARACTERISTICS (ABBREVIATED) CORRESPONDING BANK VALUE IS SHOWN IN BOLD ITALICS & $\begin{array}{l}\text { QUESTIONS FROM } \\
\text { QUESTIONNAIRE A }\end{array}$ & $\begin{array}{l}\text { \% OF RESPONDENTS WHO } \\
\text { BELIEVE THE CHARACTERISTIC } \\
\text { IS PRESENT “VERY OFTEN" OR } \\
\text { "ALL THE TIME" }\end{array}$ \\
\hline Meaningful/challenging work - Growing our people & 10 & $67,2 \%$ \\
\hline Congruence - personal and corporate values & 16 & $62.8 \%$ \\
\hline Employees share a common vision - Serving our customers. Delivering to shareholders & 16 & $62.8 \%$ \\
\hline Drawing on tolerance for diversity - Growing our people & $3 ; 6$ & $64.3 \% ; 68,5 \%$ \\
\hline Teamwork and team spirit - Working in teams & $12 ; 13 ; 15$ & $64,2 \% ; 70,0 \% ; 65,7 \%$ \\
\hline Creativity and initiative/resourcefulness - Being proactive & $14 ; 20$ & $74,3 \% ; 78,6 \%$ \\
\hline Authenticity/integrity/ethical decisions - Upholding the highest levels of integrity & $1 ; 19$ & $58,5 \% ; 57,2 \%$ \\
\hline Involvement/empowerment/participative management & $4 ; 5$ & $67,1 \% ; 71,4 \%$ \\
\hline Realisation of potential/personal growth /opportunities to learn and develop - Growing our people & $2 ; 21$ & $74,3 \% ; 67,1 \%$ \\
\hline Employees experience a sense of community - Working in teams. & 15 & $65,7 \%$ \\
\hline A sense of connectedness to others - Working in teams & 15 & $65,7 \%$ \\
\hline Positive /pleasant environment & $7 ; 8$ & $65,7 \% ; 64,3 \%$ \\
\hline Reward and recognition; acknowledgement and appreciation & $9 ; 10$ & $65,7 \% ; 67,2 \%$ \\
\hline High levels of trust and trustworthiness - Upholding the highest levels of integrity & $1 ; 19$ & $58,5 \% ; 57,2 \%$ \\
\hline Employees feel listened to & $11 ; 17$ & $55,8 \% ; 57,2 \%$ \\
\hline $\begin{array}{l}\text { Atmosphere of caring, understanding, and concern for others - Respecting each other. Guarding against } \\
\text { arrogance }\end{array}$ & $12 ; 18 ; 19$ & $64,2 \% ; 64,2 \% ; 54,20 \%$ \\
\hline Legitimate power based on respect - Respecting each other. Upholding the highest levels of integrity & 11 & $55,8 \%$ \\
\hline
\end{tabular}


line management and investigate these initiatives, with a view to assessing the impact of these initiatives on spirituality at work and living the values.

The project team should be briefed to "package" those initiatives that are identified as making a positive contribution to creating a spiritual workplace and to add these as training interventions to the branch development programme.

It is further recommended that the leaders (eight managerial staff) in the branch be used to establish a "community of practice"' to facilitate shared learning forums within the branch network.

A final recommendation is that the characteristics measured in this study (and the two questionnaires used to survey these characteristics) be added to the set of branch diagnostics to be used annually to measure employee satisfaction.

\section{Limitations}

Only one branch was surveyed in this study. No factor analysis was done due to the limited number of respondents. The results cannot be assumed to be representative of the entire bank. The study did not deal with the impact of the leadership responsible on the branch.

\section{Suggestions for further research}

Formal Research

The significant differences found in the responses across the different ethnic groups as well as tenure should be researched to understand the relevance and impact of ethnicity and tenure on spirituality at work and spiritual fulfilment. It is suggested that this survey be carried out in more branches across the branch network to assess spirituality at work (living the values) and spiritual fulfilment of employees. This would also help management understand the impact of various branch specific initiatives on spirituality at work, living the values and employee spiritual fulfilment.

\section{Functional "in branch" research}

It is suggested that further functional or "in action" research be conducted within the branch to determine what might be contributing to making the branch a spiritual workplace and

TABLE 14

Respondents who believe they are spiritually fulfilled at work 'often' and 'almost always'

\begin{tabular}{|c|c|c|}
\hline CHARACTERISTIC (ABBREVIATED) CORRESPONDING BANK VALUE IS SHOWN IN BOLD ITALICS & $\begin{array}{l}\text { QUESTIONS FROM } \\
\text { QUESTIONNAIRE B }\end{array}$ & $\begin{array}{l}\text { \% OF RESPONDENTS WHO FIND } \\
\text { "PIRITUAL FULFILMENT AT WORK } \\
\text { "OFTEN" AND "ALMOST ALWAYS" }\end{array}$ \\
\hline Meaningful/challenging Work - Growing our People & $1 ; 2 ; 3 ; 7 ; 8$ & $65,7 \% ; 68,6 \% ; 71,5 \% ; 84,3 \% ; 67,2 \%$ \\
\hline Congruence - personal and corporate values & $4 ; 21$ & $87,2 \% ; 71,4 \%$ \\
\hline Employees share a common vision - Serving our customers. Delivering to shareholders & $14 ; 15$ & $67,2 \% ; 72,8 \%$ \\
\hline Drawing on tolerance for diversity - Growing our people & $14 ; 15$ & $67,2 \% ; 72,8 \%$ \\
\hline Teamwork and team spirit - Working in teams & $14 ; 15$ & $67,2 \% ; 72,8 \%$ \\
\hline Creativity and initiative/resourcefulness - Being proactive & 17 & $77,2 \%$ \\
\hline Authenticity/integrity/ethical decisions - Upholding the highest levels of integrity & $10 ; 20 ; 21$ & $74,3 \% ; 71,4 \% ; 71,4 \%$ \\
\hline Involvement/empowerment/participative management & 5 & $71,4 \%$ \\
\hline Realisation of potential/personal growth /opportunities to learn and develop - Growing our people & $8 ; 9 ; 10$ & $67,2 \% ; 71,4 \% ; 74,3 \%$ \\
\hline Employees experience a sense of community - Working in teams & 15 & $72,8 \%$ \\
\hline A sense of connectedness to others - Working in teams & 14 & $67,2 \%$ \\
\hline Positive/pleasant environment & 6 & $62,8 \%$ \\
\hline Reward and recognition; acknowledgement and appreciation & $11 ; 12 ; 13 ; 19$ & $64,3 \% ; 54,2 \% ; 70,0 \% ; 41,4 \%$ \\
\hline High levels of trust/trustworthiness. Upholding the highest levels of integrity & $10 ; 16$ & $74,3 \% ; 55,7 \%$ \\
\hline Employees feel listened to & 12 & $54,2 \%$ \\
\hline $\begin{array}{l}\text { Atmosphere of caring, understanding, and concern for others - Respecting each other. Guarding } \\
\text { against arrogance }\end{array}$ & $9 ; 10 ; 17 ; 18$ & $71,4 \% ; 74,3 \% ; 77,2 \% 68,6 \&$ \\
\hline Legitimate power based on respect - Respecting each other. Upholding the highest levels of integrity & $10 ; 16 ; 20 ; 21$ & $74,3 \% ; 55,7 \% ; 71,4 \% ; 71,4 \%$ \\
\hline
\end{tabular}

TABLE 15

Statistics in respect of the questions measuring the characteristics linked to the value "growing our people"

\begin{tabular}{lllll}
\hline QUESTIONS & VALID & MISSING & MEAN & $\begin{array}{l}\text { STD. } \\
\text { DEVIATION }\end{array}$ \\
\hline A10 & 70 & 0 & 3.81 & .889 \\
B1; B2; B3; B7; B8 & 66 & 4 & 4.0273 & .74988 \\
A3; A6 & 69 & 1 & 3.8913 & .86121 \\
B14; B15 & 70 & 0 & 3.9643 & .89005 \\
A2; A21 & 68 & 2 & 3.9191 & .71555 \\
B8; B9; B10 & 66 & 4 & 4.0273 & .74988 \\
\hline
\end{tabular}

TABLE 16

Paired sample statistics

\begin{tabular}{llllll}
\hline PAIR & QUESTIONS & MEAN & $\mathbf{N}$ & $\begin{array}{l}\text { STD. } \\
\text { DEVIATION }\end{array}$ & CORRELATION \\
\hline \multirow{2}{*}{1} & A10; & 3.83 & 66 & .870 & .479 \\
& B1; B2; B3; B7; B8 & 4.0273 & 66 & .74988 & \\
2 & A3; A6; & 3.8913 & 69 & .86121 & .661 \\
& B14; B15 & 3.9493 & 69 & .88760 & \\
3 & A2; A21; & 3.9609 & 64 & .70319 & .575 \\
& B8; B9; B10 & 4.0313 & 64 & .70952 & \\
\hline
\end{tabular}

TABLE 17

Paired sample tests

\begin{tabular}{|c|c|c|c|c|c|c|}
\hline \multirow[b]{2}{*}{ PAIR } & \multirow[b]{2}{*}{ QUESTIONS } & \multicolumn{2}{|c|}{ PAIRED DIFFERENCES } & \multirow[b]{2}{*}{$T$} & \multirow[b]{2}{*}{ DF } & \multirow[b]{2}{*}{$\begin{array}{l}\text { SIG. (2- } \\
\text { TAILED) }\end{array}$} \\
\hline & & MEAN & $\begin{array}{l}\text { STD. } \\
\text { DEVIATION }\end{array}$ & & & \\
\hline 1 & $\begin{array}{l}\text { A10 } \\
\text { B1; B2; B3; B7; B8 }\end{array}$ & -.19394 & .83314 & -1.891 & 65 & .063 \\
\hline 2 & $\begin{array}{l}\text { A3; A6 } \\
\text { B14; B15 }\end{array}$ & -.05797 & .72017 & -.669 & 68 & .506 \\
\hline 3 & $\begin{array}{l}\text { A2; A21 } \\
\text { B8; B9; B10 }\end{array}$ & -.07031 & .65115 & -.864 & 63 & 391 \\
\hline
\end{tabular}

TABLE 18

Reliability statistics for paired samples

\begin{tabular}{lll}
\hline QUESTIONS & CRONBACH'S ALPHA & NUMBER OF ITEMS \\
\hline A10 & NA & NA \\
B1; B2; B3; B7; B8 & .863 & 5 \\
A3; A6 & .797 & 2 \\
B14; B15 & .809 & 2 \\
A2; A21 & .659 & 2 \\
B8; B9; B10 & .710 & 3 \\
\hline
\end{tabular}


ensuring employees in the branch live the values. This study has dealt with the question: Is this workplace a spiritual workplace and do the employees experience spiritual fulfilment at work? It has not dealt with the possible reasons for this. The impact of the branch leadership and the initiatives in the branch should be assessed, and to the extent that these are contributing to spirituality at work and spiritual fulfilment at work, these initiatives should be "packaged" as lessons learned and replicated across the branch network.

\section{REFERENCES}

Aburdene, P. (2005). Megatrends 2010: the rise of conscious capitalism. Charlottesville: Hampton Road Publishing Company.

Ashmos, D.P. \& Duchon, D. (2002). Spirituality at work: a conceptualization and measure. Unpublished manuscript, San Antonio: University of Texas.

Bank HR Board Report, April 2006.

Barrett, R. (1998). Liberating the corporate soul: building a visionary organization. USA: Butterworth-Heinemann.

CEO Road show - "Living the Values".

Covey, S.R. (1989). The seven habits of highly effective people. London: Simon \& Schuster.

Deloitte, Touche \& Tohmatsu, (2006). Results: building and delivering on your employer brand. Retrieved January 20, 2007, from the World Wide Web: http://www.bestcompany.co.za

Gibbons, P. (2002). Spirituality at work: definitions, measures, assumptions, and validity claims. Paper presented at EURAM conference, August 2002.

Howard, S. \& Welbourn, D. (2004). The spirit at work phenomenon. Great Britain: Azure.

Humphreys, T. (2000). Work and worth. Dublin: Newleaf.

Lamont, G. (2002). The spirited business. Great Britain: Hodder \& Stoughton.
Leedy, P. \& Ormrod, J.E. (2001). Practical research: Planning and design. New Jersey: Prentice Hall.

Marques, J., Dhiman, S. \& King, R. (2005) Spirituality at Work. The Journal of American Academy of Business, 7(2), 1-2.

Miller, W.C. (2003). The art of spiritual leadership in business: how to lead with spirituality, purpose, values and creativity. Sounds True.4 CDs - running time 4 hours. ISBN: 1-59179-019 USA.

Mitroff, I. \& Denton, E.A. (1999). A spiritual audit of corporate America. San Francisco: Jossey-Bass.

Parker, C. (2005). Beyond positions and possessions - finding your place at work. Indwe - South African Express Airways inflight magazine. Pretoria: Siyaya Publishing, pp. 8-9.

Smith, D.P.J. (2005). Personal leadership A. Unpublished notes, Johannesburg: University of Johannesburg.

Smith, D.P.J. (2006). The concept spirituality - a PiPL-perspective. Monograph, Johannesburg: University of Johannesburg.

Smith, D.P.J. \& Louw, M. (2007). Conceptualisation of the spiritual life dimension: a personal and professional leadership perspective. SA Journal of Human Resource Management, 5(1), 19-27.

Toms, M. (1997). The soul of business. Great Britain: Hay House.

Verrier, D. (2002). Spiritual fulfilment in a utility company of the City of Johannesburg: a phenomenological study. Unpublished research essay, Johannesburg: University of Johannesburg.

Verrier, D. (2005). Executive coaching: a Personal and professional leadership (PPL) perspective. Unpublished doctoral thesis, Johannesburg: University of Johannesburg.

Verrier, D. \& Smith, D.P.J. (2006). Spirituality at work: a pivotal postmodern paradigm for determining success or failure in business in the twenty-first century. HR Future, January 2006. pp.37-38. Retrieved July, 2007 from the World Wide Web: http://www.hrfuture,net/

Zohar, D. \& Marshall, I. (2004). Spiritual capital. Great Britain: Bloomsbury. 